\title{
The carbon isotopic composition of dissolved inorganic carbon in perennially ice-covered Antarctic lakes: searching for a biogenic signature
}

\author{
Klaus NEUMANN, ${ }^{1}$ W. Berry LYONS, ${ }^{2}$ John C. PRISCU, ${ }^{3}$ David J. DESMARAIS, ${ }^{4}$ \\ Kathleen A. WELCH ${ }^{2}$ \\ ${ }^{1}$ Department of Geology, Ball State University, Muncie, IN 47306, USA \\ ${ }^{2}$ Byrd Polar Research Center, The Ohio State University, 1090 Carmack Road, Columbus, OH 43210-1002, USA \\ E-mail: lyons.142@osu.edu \\ ${ }^{3}$ Land Resources and Environmental Sciences, Montana State University, Bozeman, MT 59717, USA \\ ${ }^{4}$ NASA Ames Research Center, Moffett Field, CA 94035, USA
}

\begin{abstract}
The stable-isotopic signature of dissolved inorganic carbon (DIC) has been routinely used in temperate lake systems to investigate the biogeochemical dynamics of carbon. We studied seven perennially ice-covered lakes in the McMurdo Dry Valleys, Antarctica, to ascertain how carbon cycling affects the $\delta^{13} \mathrm{C}$ of DIC in water columns of these systems. Unlike temperate lakes and, in fact, most polar lake systems, the permanent ice covers of these lakes eliminate physical mixing (turnover) and hence redistribution of DIC in the lakes, as well as minimize $\mathrm{CO}_{2}$ exchange with the atmosphere. These important and unique physical constraints have significant impact on carbon dynamics in the lakes, and important consequences for the $\delta^{13} \mathrm{C}$ distribution. The geochemistry in these lakes is influenced in varying amounts by landscape position, hydrologic input and their evolutionary history. Five of these lakes (both lobes of Lake Bonney, and Lakes Fryxell, Miers and Vanda) have surface water $\delta^{13} \mathrm{C}$ ratios of 0-4\%, Lake Hoare has more negative values, while Lake Joyce, the highest-elevation lake, has a much higher value $(10.5 \%)$. All of the lakes have upper- to mid-depth $\delta^{13} \mathrm{C}$ maxima reflecting biological uptake of ${ }^{12} \mathrm{C}$. Only four of the lakes (Lakes Vanda, Joyce, Hoare and Fryxell) have deep waters with negative values of $\delta^{13} \mathrm{C}$, implying rigorous remineralization of ${ }^{12} \mathrm{C}$ at depth. Lake Miers, the only lake that is not closed basin, has the smallest $\delta^{13} \mathrm{C}$ variation with depth, indicating that hydrologic exchange greatly influences the $\delta^{13} \mathrm{C}$ signal.
\end{abstract}

\section{INTRODUCTION}

Understanding the biogeochemistry of perennially icecovered aquatic systems has become an important prerequisite to understanding a number of current scientifically intriguing problems, including the documentation of life on ancient Mars (Doran and others, 1998), in subglacial lakes in Antarctica (e.g. Vostok lake) (Priscu and others, 1999a; Siegert and others, 2003) and the biological consequences of a Neoproterozoic 'snowball Earth' (Fairchild, 1993; Hoffman and Schrag, 2002). The perennially ice-covered closed-basin lakes of the McMurdo Dry Valleys (MCM) region of Antarctica $\left(\sim 78^{\circ} \mathrm{S}\right)$ offer a unique opportunity to compare biological processes to the imprint that they produce via the transfer of carbon within the lakes. Although the MCM lakes are clearly very different from the subglacial lakes on the continent, the investigation of these lakes offers some important insights into the role that perennial ice cover has in the biogeochemistry of aquatic systems. These MCM lakes are photosynthetic in nature, with photosynthesis being the primary driver of carbon fixation in the ecosystem, yet, in contrast to temperate systems, the lack of direct contact with the atmosphere minimizes gas exchange, winddriven mixing, temperature-driven density change and lake turnover. The $\delta^{13} \mathrm{C}$ composition of either the solutes or the inorganic materials produced within the waters provides important clues to the biological processes that have occurred within these ice-covered systems (McKenzie, 1985). Because biological activity is closely connected to the carbon cycle, both photosynthesis and respiration change the $\delta^{13} \mathrm{C}$ distribution of dissolved inorganic carbon (DIC) in aquatic systems (Quay and others, 1986). In this paper, we report for the first time, the $\delta^{13} \mathrm{C}$ ratios of DIC in five lakes from the MCM region (Lakes Miers, Joyce, Vanda and both the east and west lobes of Lake Bonney). The data, when compared and contrasted to previously published $\delta^{13} \mathrm{C}-\mathrm{DIC}$ profiles of Lakes Fryxell and Hoare (Neumann and others, 1998), allow for a much clearer indication of how biological processes affect the isotopic composition in these ice-covered systems. The interpretation of these data from the MCM lakes should aid in the interpretation of $\delta^{13} \mathrm{C}$ data collected from other ice-covered systems.

\section{SITE DESCRIPTION}

The MCM region is the largest ice-free area in Antarctica. The perennially ice-covered lakes in MCM have been investigated since the International Geophysical Year 1957/ 58 , but only since a US National Science Foundation (NSF)sponsored long-term ecological research (LTER) site was established there in 1993 have they been studied in an interdisciplinary manner (http://huey.colorado.edu). Since this time, biological, chemical, glaciological and meteorological measurements have been made on a routine basis. The primary site of the MCM-LTER is Taylor Valley, although measurements are also made less frequently in a number of the nearby valleys (Fig. 1). The MCM region is a polar desert 

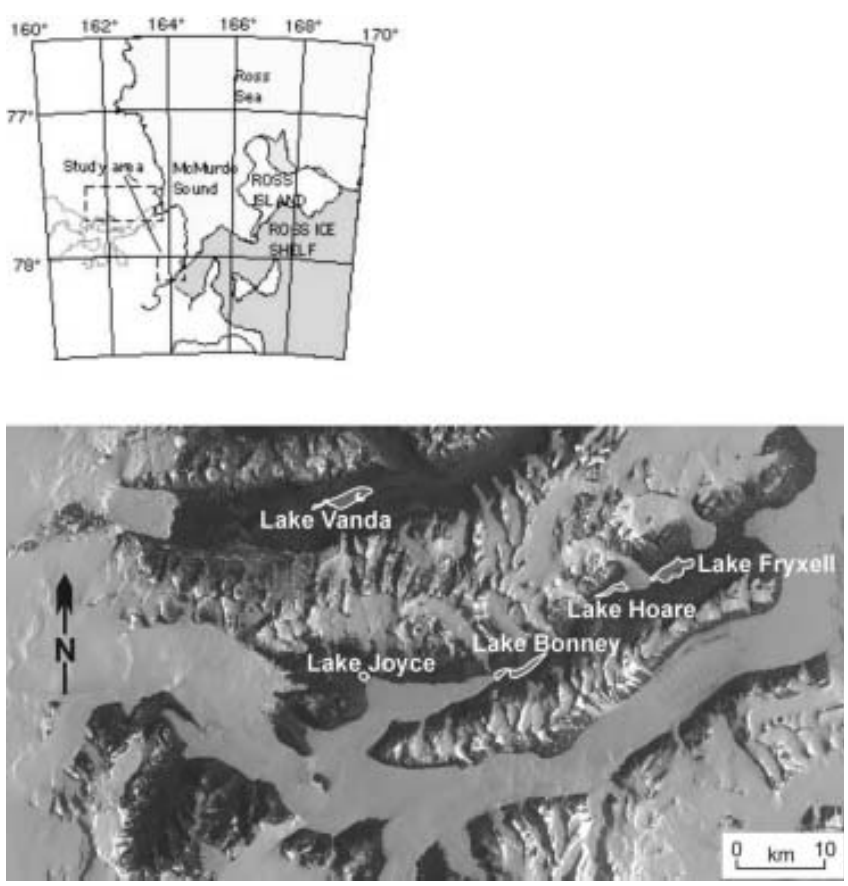

Fig. 1. Location of study area and McMurdo Dry Valleys lakes sampled in this investigation.

with water equivalent precipitation rates $\leq 100 \mathrm{~mm} \mathrm{a}^{-1}$ (Clow and others, 1988). Temperatures vary by location, but all of the MCM-LTER meteorological station locations have mean annual temperatures at or below $-16.8^{\circ} \mathrm{C}$. The lakes in MCM gain water in the austral summer during a few weeks of glacier meltwater production, and, with the exception of Lake Miers, only lose water through freeze-on to the ice cover and eventual sublimation at the surface. Lake Miers is the only lake in this group that has an outlet stream; therefore it also loses water via outflow. The other lakes are closed-basin lakes and represent a terminus of water flow in each of their basins. Much has been written on the hydrology of these systems, especially the Taylor Valley systems (McKnight and others, 1999). The physical description of these lakes is provided in detail in Spigel and Priscu (1998) and will not be repeated here. With the exception of Lake Miers, these lakes are chemically stratified, with the hypolimnia of Lakes Fryxell and Joyce being brackish and those of Lakes Bonney and Vanda being hypersaline. The density stratification in these lakes (with the exception of Lake Hoare) is due to previous changes in climate, and their hypolimnetic waters represent 'older' water introduced to the lakes in the past (Lyons and others, 2000). The stable density structure of Lakes Bonney, Fryxell, Vanda and Joyce and lack of wind-driven circulation minimize water exchange between the surface and deep waters. Lakes Bonney, Fryxell and Hoare have been sampled at least twice during the austral summer since the beginning of the LTER effort in 1993, while Lakes Vanda, Miers and Joyce have been sampled much less frequently. Ice thicknesses of these lakes from the 1960s through the 1980s varied from 2.5 to $6.0 \mathrm{~m}$ depending on season and year, with Lake Joyce generally having the thickest ice (Wharton and others, 1993). Annual ablation of ice from the surface of the lakes is on the order of $35 \mathrm{~cm} \mathrm{a}^{-1}$ (Clow and others, 1988), and the ice cover is maintained by refreezing lake surface water onto the bottom of the ice cover during winter.

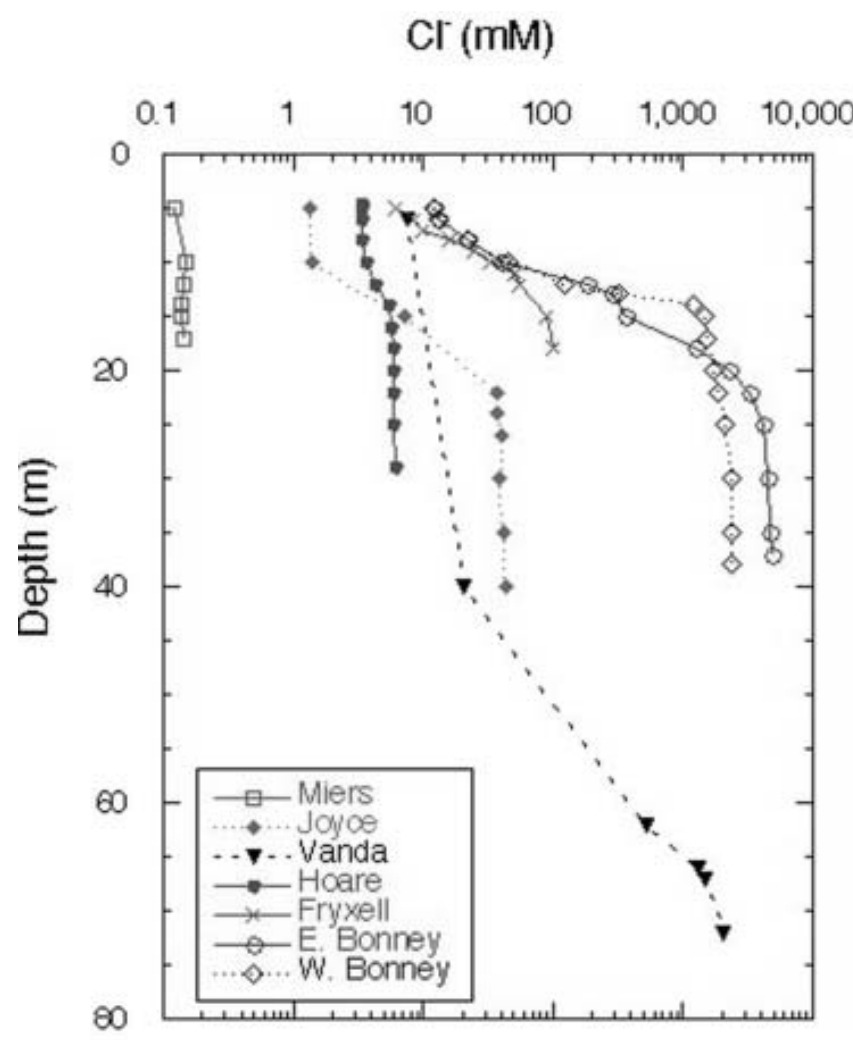

Fig. 2. Chloride concentrations vs depth in MCM lakes.

\section{METHODS}

Water samples were collected by standard limnological techniques using $5 \mathrm{~L}$ Niskin bottles during the 1994/95 and 1996/97 austral summers and represent a one-time sampling effort. Although long-term data exist for Lakes Bonney, Fryxell and Hoare for $\mathrm{Cl}^{-}$and DIC, the data presented are only from the sampling times when the $\delta^{13} \mathrm{C}$ samples were collected. The long-term data for the lakes can be seen at http://huey.colorado.edu. Samples were collected through the water column over the deepest part of each lake. Samples for major ions were filtered within hours of collection through $0.4 \mu \mathrm{m}$ Corning Nucleopore ${ }^{\mathrm{TM}}$ filters in precleaned plastic filtering units. DIC samples were collected in $60 \mathrm{~mL}$ serum vials, stabilized with chloroform, capped and sealed, and stored in the dark at $4{ }^{\circ} \mathrm{C}$. Within 2 weeks, these samples were analyzed using a MSA Lira infrared gas analyzer after acid sparging with $6 \mathrm{~N} \mathrm{H}_{2} \mathrm{SO}_{4}$. Chloride was measured on filtered samples using a Dionex DX-300 ion chromatograph (Welch and others, 1996). Precision of the $\mathrm{Cl}^{-}$ranged between $0.7 \%$ and $0.9 \%$, and that of DIC ranged from $1.8 \%$ to $2.8 \%$ for the Taylor Valley lakes. Samples for $\delta^{13} \mathrm{C}$ analysis were filtered into preevacuated $60 \mathrm{~mL}$ serum bottles using Whatman GF/F filters and stabilized by the addition of $0.2 \mathrm{~mL}$ saturated $\mathrm{HgCl}_{2}$ solution. Samples were analyzed at the NASA Ames Research Center on a modified Nuclide 6-6ORMS mass spectrometer. Precision of these measurements was $1.5 \%$.

\section{RESULTS}

The $\mathrm{Cl}^{-}$profiles for the seven lakes (the two lobes of Lake Bonney are considered to be distinct lakes) are shown in Figure 2. Lake Miers, the lake with an outflowing stream, has 


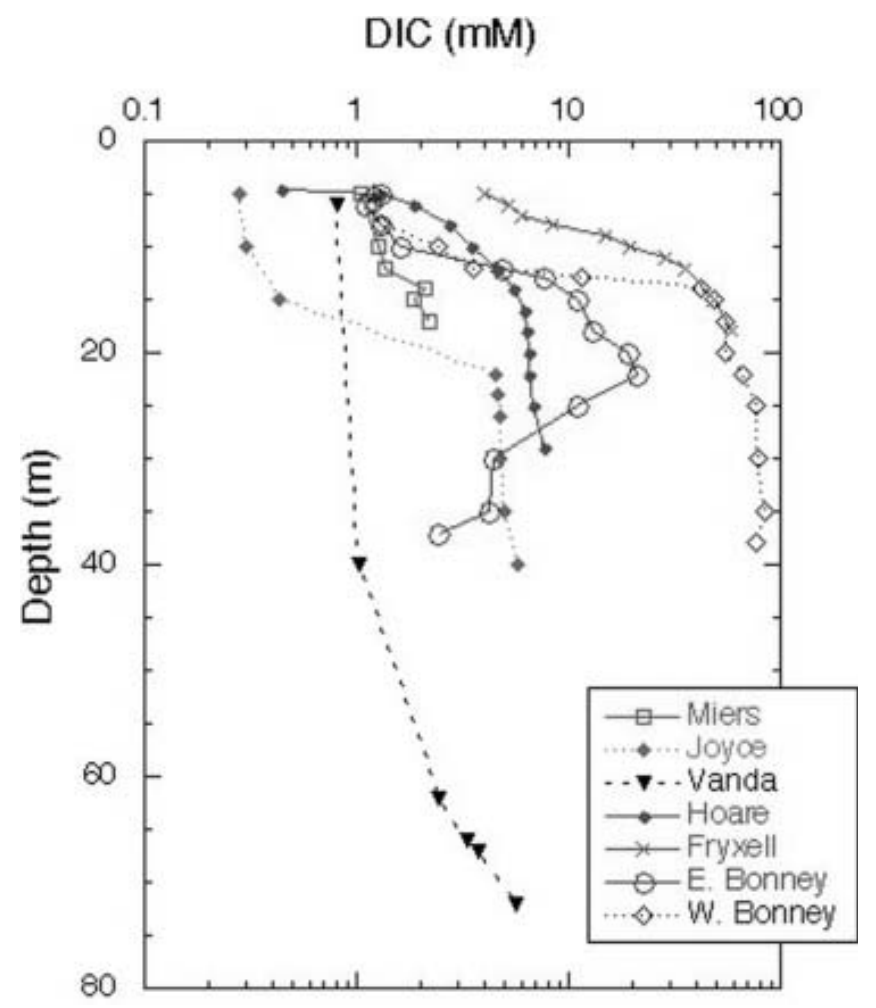

Fig. 3. DIC concentrations vs depth in MCM lakes.

the lowest $\mathrm{Cl}^{-}$concentrations. Of the closed-basin systems, Lake Hoare is the freshest, followed by Lakes Joyce and Fryxell, which are considered to be brackish water lakes. As mentioned above, Lakes Bonney and Vanda have hypersaline hypolimnia (Fig. 2). The high $\mathrm{Cl}^{-}$concentrations in the bottom waters of these lakes reflect, in part, past climatic variation in the MCM, including the loss of the ice covers of these lakes, the regaining of those ice covers and the subsequent refilling of the lakes. This event occurred $\sim 1 \mathrm{kyr}$ ago for most of these lakes, although the timing of this event in Lake Joyce is unknown (Matsubaya and others, 1979; Lyons and others, 1998b). Therefore the hypolimnia of these lakes represents older waters that have been removed from contact with the atmosphere. The $\mathrm{Cl}^{-}$concentrations increase with depth in all lakes, other than Lake Miers (Fig. 2). The DIC data for the lakes are plotted in Figure 3. The DIC concentrations range from a low of $0.28 \mathrm{mM}$ in the surface waters of Lake Joyce to values of $84.7 \mathrm{mM}$ at $35 \mathrm{~m}$ in the west lobe of Lake Bonney (Fig. 3). With the exception of the east lobe of Lake Bonney, the concentrations generally increase with depth, reflecting the evaporative concentration from the drawdown event outlined above, mineralization of organic matter and dissolution of $\mathrm{CaCO}_{3}$, depending on the lake (Neumann, 1999). The $\delta^{13} \mathrm{C}$ ratios of the DIC are plotted vs depth in Figure 4. Four of the lakes have $\delta^{13} \mathrm{C}$ ratios in the surface waters of $2-4 \%$, one of the lakes has more negative $\delta^{13} \mathrm{C}$ ratios, while Lake Joyce has a much higher ratio at $\sim 10.5 \%$. All the lakes have upper- to mid-depth maxima of $\delta^{13} \mathrm{C}$ (Fig. 4). Chlorophyll-a (Chl-a) samples were taken at the same time as the geochemistry samples, with the exception of Lake Vanda, which was sampled for Chl-a a few days later; all the data are shown in Figure 5. Lakes Fryxell, Hoare and the east lobe of Lake Bonney have distinct upper-layer (directly below the ice cover) maxima, while the west lobe of Lake Bonney and

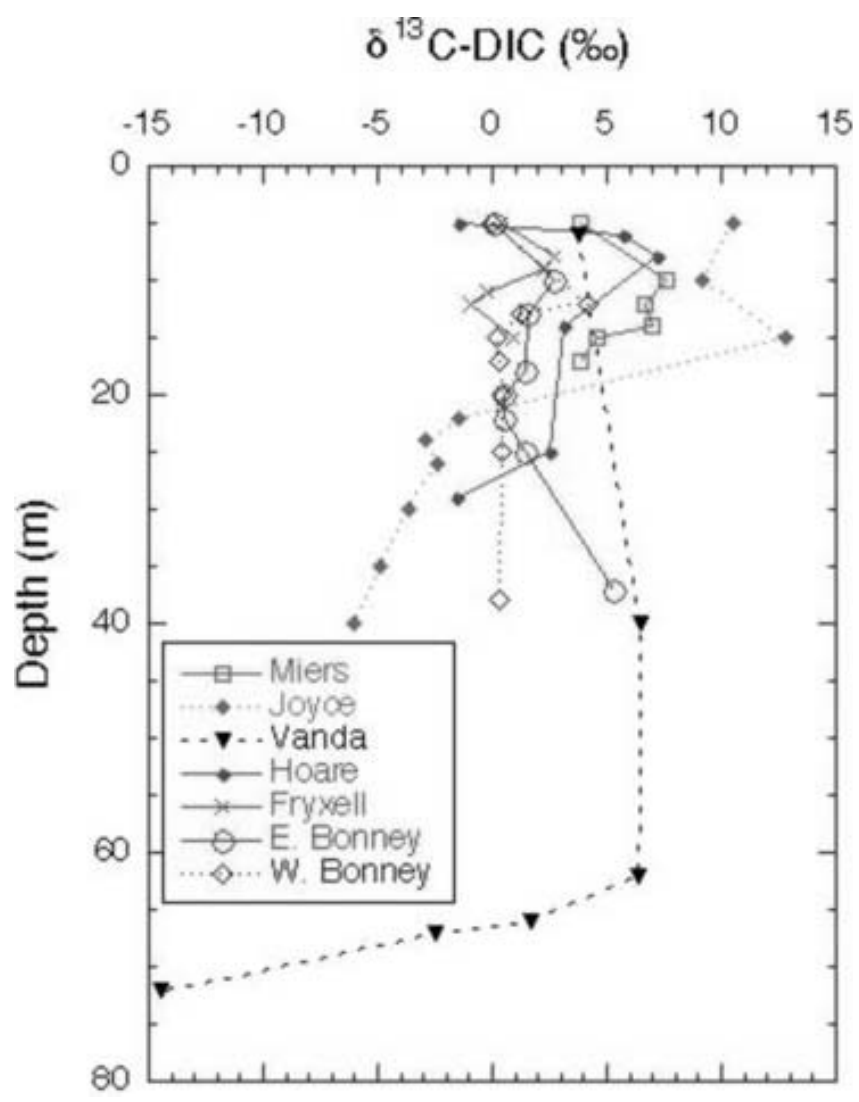

Fig. 4. $\delta^{13} \mathrm{C}$ of DIC vs depth in MCM lakes.

Lake Joyce have deeper maxima. Lake Miers has the most unusual $\mathrm{Chl}-\mathrm{a}$ profile, with a mid-depth minimum and a bottom-water maximum (Fig. 5). Primary productivity rate (PPR) data only exist for four of the lakes and were obtained at the same time as the geochemical and Chl-a profiles (Fig. 6). Lake Hoare and both lobes of Lake Bonney have mid-water maxima, while Lake Fryxell has an upper-layer maximum. The highest PPR values approach $12 \mu \mathrm{gCL}^{-1} \mathrm{~d}^{-1}$ (Fig. 6). These are low-productivity systems that are greatly influenced by mixotrophy (Laybourn-Parry, 1997; Priscu and others, 1999b).

\section{DISCUSSION}

\section{DIC profiles}

The profiles of DIC concentration in the lakes have been influenced by a number of processes, including past lake history (i.e. the accumulation of carbon via lake drawdown, or what we have termed legacy events), stream input (i.e. landscape position) and in-lake processes, both biochemical and geochemical. Therefore the DIC and its $\delta^{13} \mathrm{C}$ signature in the hypolimnia of these lakes represent the consequences of both current and past geochemical and biogeochemical processes occurring in the lakes. This is the case because, with the exception of Lake Miers, the closed-basin nature of the lakes negates the loss of carbon through water outflow. Lake Fryxell receives a very large percentage of its water input from streams, as opposed to direct runoff from glaciers. Stream-waters are enriched in DIC through the dissolution of $\mathrm{CaCO}_{3}$ and the weathering of silicate minerals (Nezat and others, 2001). Lakes Bonney and Miers also have higher 


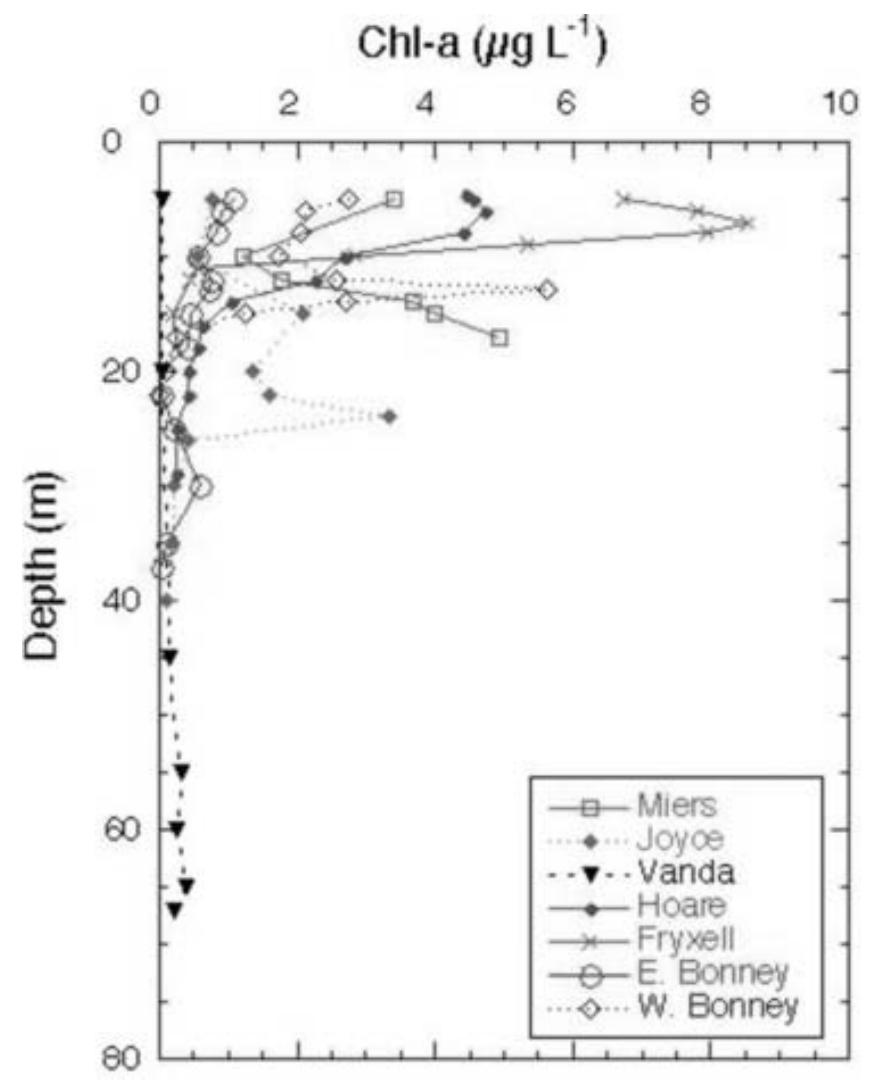

Fig. 5. Chl-a concentrations vs depth in MCM lakes.

inputs of DIC than the other lakes due to a higher percentage of stream input (Neumann and others, 1998), which leads to higher DIC concentrations in the surface waters of these lakes (Fig. 3). The proglacial lakes, Lakes Hoare and Joyce, which receive their recharge directly via glaciers, have lower concentrations of DIC in the surface. Lake Vanda, which is fed by the longest river on the continent, the Onyx River, has intermediate surface water DIC concentration. This may be due, in part, to uptake by the abundant photosynthetic cyanobacteria in the river bed. The lakes with known historic drawdown events, such as Lakes Bonney, Fryxell and Vanda (Wilson, 1964; Matsubaya and others, 1979; Lyons and others, 1998b), have much higher DIC concentrations in their hypolimnia. The highest values are in the west lobe of Lake Bonney, in part because this lake has not lost its ice cover over the past few millennia (based on $\delta^{18} \mathrm{O}$ and $\delta \mathrm{D}$ profiles of the water column (Matsubaya and others, 1979)), as have Lakes Vanda and Fryxell and the east lobe of Lake Bonney. The loss of the ice cover allowed for the loss of DIC both through $\mathrm{CO}_{2}$ degassing and through concentration of the lake waters and the precipitation of carbonate minerals. It is possible that Lake Joyce proceeded through a similar drawdown event prior to $\sim 1000$ years $B P$, which would explain the higher DIC concentrations in its hypolimnion. The DIC profiles in Lakes Miers and Hoare represent more modern ( $\sim 1000$ year) accumulation of DIC at depth.

Thermodynamic mineral solubility calculations using PHRQPITZ indicate that the deep waters of Lake Hoare and the west lobe of Lake Bonney are undersaturated with respect to calcite, while the deep waters of Lakes Fryxell, Joyce, Vanda and the east lobe of Lake Bonney are

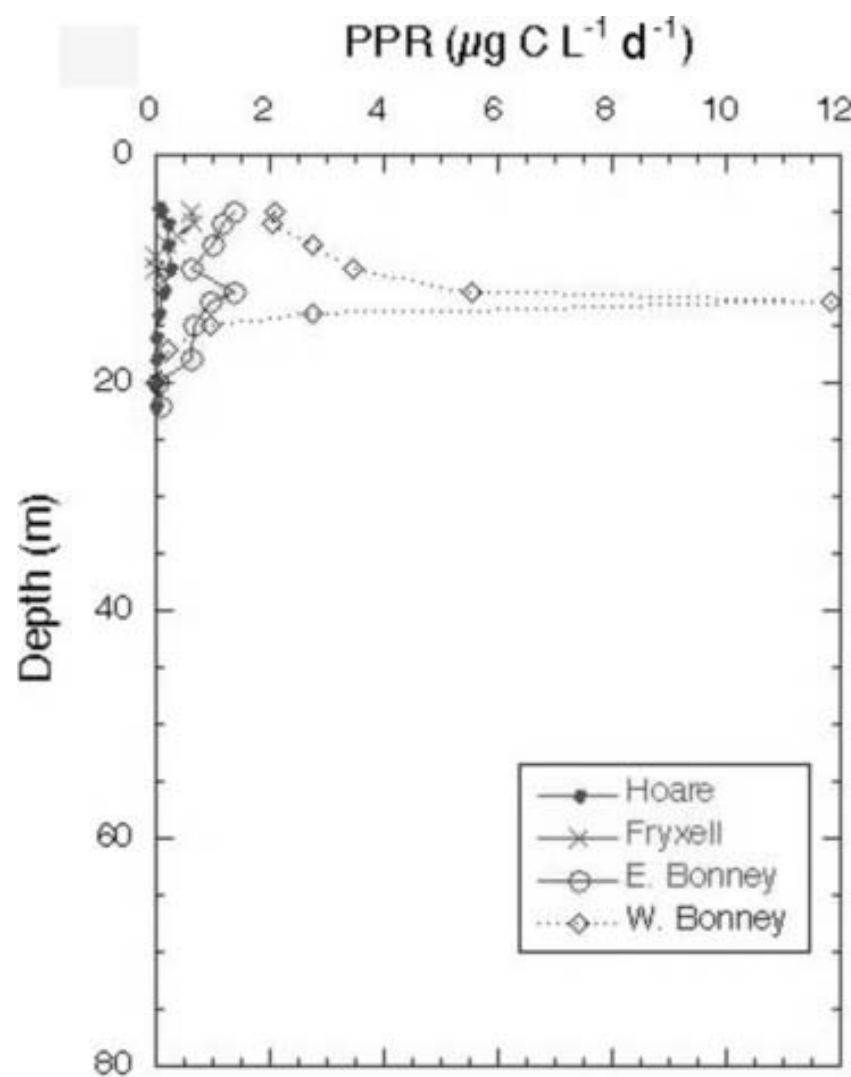

Fig. 6. Primary production rates as measured through ${ }^{14} \mathrm{C}$ uptake during a 24 hour incubation vs depth in MCM lakes.

supersaturated with respect to calcite (Lyons and others, 1998a; Neumann, unpublished information). Lake Miers is slightly supersaturated with respect to calcite from 10 to $14 \mathrm{~m}$, but is slightly undersaturated elsewhere. The surface waters of both lobes of Lake Bonney and of Lake Fryxell proceed from supersaturated to undersaturated with respect to calcite as the austral summer proceeds and stream-water enters the lakes. In addition to the potential carbon uptake and input from calcium carbonate dynamics within the lakes, carbon uptake through photosynthesis in the mid- to upper portions of the lakes and input through mineralization of organic matter at depth also play a potentially important role in carbon geochemistry in these systems (Neumann, 1999). Early-season photosynthesis decreases the $\mathrm{CO}_{2}$ concentrations in the surface waters of many of these lakes, and because their ice covers limit atmospheric exchange, $\mathrm{CO}_{2}$ may become a limiting nutrient (Neumann and others, 2001). Based on the PPR and Chl-a data alone, we hypothesize that DIC uptake in the euphotic zone would be greatest in the west lobe of Lake Bonney and in Lake Fryxell.

\section{$\delta^{13} \mathrm{C}$ profiles}

Studies utilizing stable isotopes have proven to be very effective for investigating carbon cycling in aquatic systems (e.g. McKenzie, 1985; Quay and others, 1986; Rau and others, 1997). The fractionation of inorganic carbon during carbonate mineral formation at the temperatures of these waters is $1-2 \%$ at $0^{\circ} \mathrm{C}$. Therefore the precipitation of $\mathrm{CaCO}_{3}$ in surface waters and its subsequent dissolution at depth could increase the bottom-water $\delta^{13} \mathrm{C}$, while the precipitation of $\mathrm{CaCO}_{3}$ could potentially decrease the $\delta^{13} \mathrm{C}$ values in 


\section{$\mathrm{DIC}: \mathrm{Cl}$ (molar ratio)}

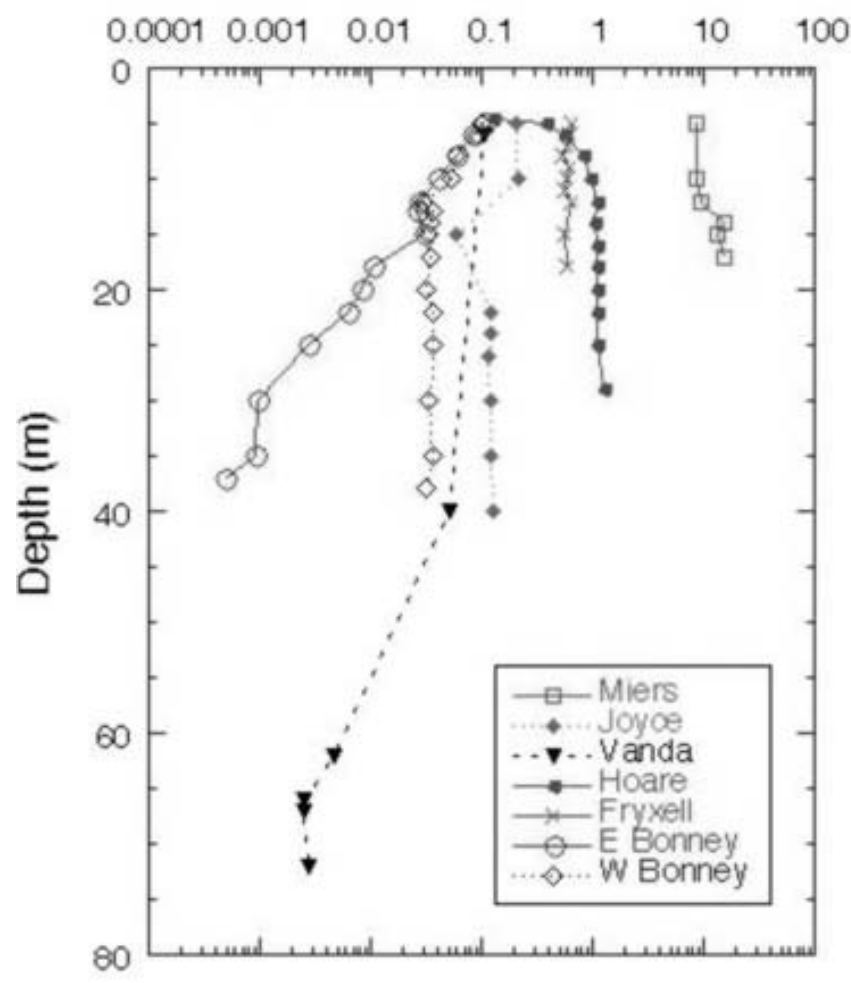

Fig. 7. $\mathrm{DIC}: \mathrm{Cl}^{-}$ratio vs depth in MCM lakes.

the water column. Conversely, if abundant $\mathrm{CO}_{2}$ is available, photosynthetic activity preferentially utilizes ${ }^{12} \mathrm{C}$, leaving the residual DIC enriched in ${ }^{13} \mathrm{C}$. As noted above, because of the ice covers on these lakes, surface waters can become very depleted in $\mathrm{CO}_{2}$ in the earliest part of the growing season (Neumann and others, 2001), which in turn produces organic carbon more enriched in ${ }^{13} \mathrm{C}$ (i.e. less fractionated), and DIC enriched in ${ }^{13} \mathrm{C}$ in the water column. The mineralization of this organic matter produced via photosynthesis would lead to DIC enriched in ${ }^{12} \mathrm{C}$.

Using stream-flow data and the $\delta^{13} \mathrm{C}$ ratios of DIC for the streams (Neumann, 1999), we have calculated the $\delta^{13} \mathrm{C}$ input into each of the three Taylor Valley lakes during the 1996/97 season. The flow-weighted values for the $\delta^{13} \mathrm{C}$ of DIC entering Lakes Bonney, Fryxell and Hoare are $-0.86 \%$, $-0.33 \%$ and $-0.04 \%$, respectively. If these values are representative of $\delta^{13} \mathrm{C}$ of DIC entering the lakes over time, it is clear that the surface waters have been greatly enriched via photosynthesis. The exception to this is Lake Hoare whose surface waters are more depleted than the incoming stream-water. However, it should be noted that because Lake Hoare is a proglacial lake, a high percentage of its surface inflow is suspected to come directly from glacial melt or from supraglacial streams (House and others, 1995). These waters could have more negative $\delta^{13} \mathrm{C}$ ratios than the streams. The $\delta^{13} \mathrm{C}$ maximum at mid-depths clearly represents a biological signal as the lighter isotope is depleted due to photosynthesis. More negative values of $\delta^{13} \mathrm{C}$ at depth in the lakes suggest remineralization of ${ }^{12} \mathrm{C}$-enriched organic matter there.

These lakes undergo cryoconcentration of solutes as water is frozen onto the bottom of the ice cover every winter while the solutes remain in the liquid phase. Some of the variation of DIC is due to this effect. By normalizing DIC to

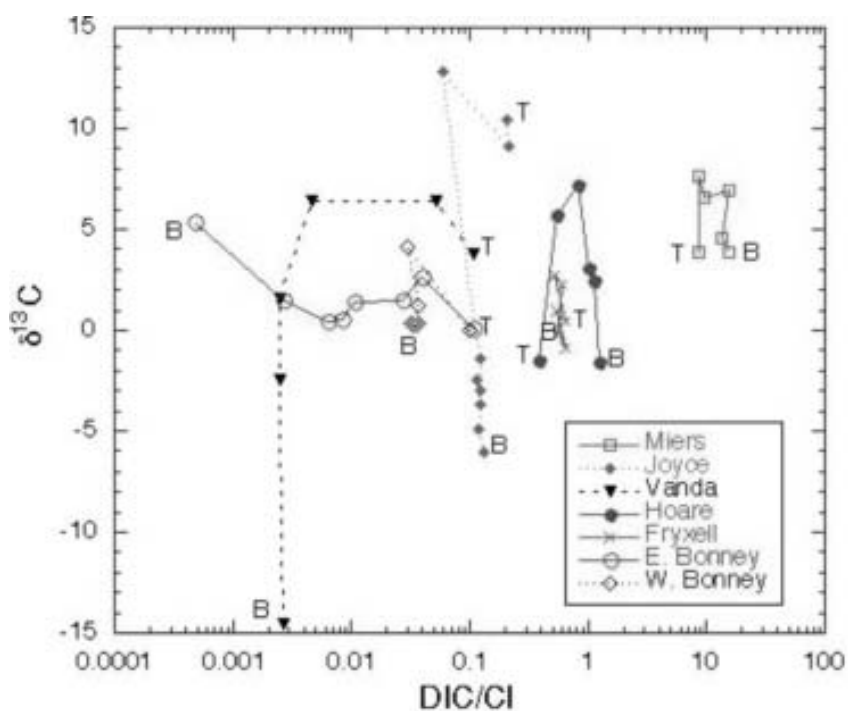

Fig. 8. $\delta^{13} \mathrm{C}$ of $\mathrm{DIC}$ vs $\mathrm{DIC}: \mathrm{Cl}^{-}$ratio in $\mathrm{MCM}$ lakes. $\mathrm{T}$ and $\mathrm{B}$ represent the top and bottom of the water column, respectively.

$\mathrm{Cl}^{-}$(Fig. 7), a better assessment of non-conservative processes controlling DIC and hence the $\delta^{13} \mathrm{C}$ variation can be made. DIC : $\mathrm{Cl}^{-}$vs $\delta^{13} \mathrm{C}$ of the DIC is shown for all the lakes in Figure 8.

In general, all the lakes except for the east lobe of Lake Bonney become depleted in $\delta^{13} \mathrm{C}$ from mid-depths to the bottom. DIC : $\mathrm{Cl}^{-}$in the west lobe of Lake Bonney and Lakes Joyce, Fryxell and Vanda either shows a decrease or remains constant with depth, coincident with an increase in $\delta^{13} \mathrm{C}$ from the surface to mid-depths, and a decrease in $\delta^{13} \mathrm{C}$ in the bottom of the water column. Biological processes discussed above can be used to explain this pattern (i.e. uptake of ${ }^{12} \mathrm{C}$ in the euphotic zone and subsequent mineralization of this light carbon in the deep waters). There are notable exceptions to this general trend, however. For example, in Lakes Hoare and Miers, while the $\delta^{13} \mathrm{C}$ of the DIC is highest at mid-depths in the water column, which follows the general pattern described above, the DIC concentration increases relative to $\mathrm{Cl}^{-}$with depth. As the waters are not undersaturated with respect to carbonate mineral phases at these depths, our explanation for this is, in part, that the $\mathrm{DIC}: \mathrm{Cl}^{-}$of this water must have been larger than that of the most recent water entering the lake. Lake Vanda shows only a slight decrease in DIC: $\mathrm{Cl}^{-}$with depth, although the $\delta^{13} \mathrm{C}$ becomes significantly more negative. This reflects the ultraoligotrophic nature of the lake, with very low primary production, biomass and respiration (Fig. 6). Lake Fryxell is more complex than the previously mentioned lakes, with more variation in $\delta^{13} \mathrm{C}$ with depth and fairly constant DIC : $\mathrm{Cl}^{-}$(Figs 7 and 8 ). The heavier $\delta^{13} \mathrm{C}$ values at depth in the lake reflect methane production there (Smith and others, 1993). During methane production, bacteria preferentially reduce ${ }^{12} \mathrm{C}$, leaving the residual DIC enriched in ${ }^{13} \mathrm{C}$. Both Lakes Joyce and Vanda show dramatic depletions of ${ }^{13} \mathrm{C}$ with depth, with little to no change in DIC: $\mathrm{Cl}^{-}$(Fig. 8). These profiles relate to past conditions where at lower lake levels there was more biological productivity. Priscu and others (1999b) have speculated that at lower lake stands, these lakes were more autotrophic than they are now. Perhaps this change in trophic status of these lakes over time has led to the observed isotopic compositions. 
The east lobe of Lake Bonney shows a very different pattern than the other lakes (Fig. 7). Its DIC concentration relative to $\mathrm{Cl}^{-}$decreases with depth, while the deepest waters have the heaviest $\delta^{13} \mathrm{C}$. As mentioned above, this pattern represents a legacy of past climate change, when this lobe of Lake Bonney had no ice cover. The work of Matsubaya and others (1979) and some of our own (R. J. Poreda and others, unpublished information) indicate that the east lobe has only had its current ice cover for 300 years. The DIC: $\mathrm{Cl}^{-}$pattern in the east lobe of Lake Bonney represents the influence of extensive water loss and concentration of solutes, leading to the precipitation and possible subsequent dissolution of carbonate minerals, mixing with west lobe waters, and not to any biological processes as the DIC: $\mathrm{Cl}^{-}$patterns in the other lakes do. Clearly for the majority of these lakes the primary influences on the $\delta^{13} \mathrm{C}$ of the DIC are biological: photosynthesis and organic-matter decomposition.

\section{Comparison of MCM lakes to other lacustrine systems}

The stable-isotopic dynamics of DIC in the MCM lakes have both similarities and differences with lakes that do not maintain a permanent ice cover. Clearly, current biologicalphysical coupled processes influence the $\delta^{13} \mathrm{C}$ signature of the DIC in the MCM lakes. For example, the uptake of ${ }^{12} \mathrm{C}$ relative to ${ }^{13} \mathrm{C}$ by photosynthetic organisms leads to heavier $\delta{ }^{13} \mathrm{C}$-DIC values in the water column where photosynthesis is occurring, i.e. at the location of the chlorophyll maxima, and lighter $\delta^{13} \mathrm{C}$ values where this organic matter is being decomposed. This is similar to the distribution observed in temperate lakes (see Quay and others, 1986). The influence of methanogenesis such as observed in the bottom waters of Lake Fryxell, and the subsequent production of heavier $\delta{ }^{13} \mathrm{C}$-DIC values is also similar to what is observed in temperate systems. Therefore biological processes imprint the $\delta^{13} \mathrm{C}$ signature and affect the $\delta^{13} \mathrm{C}$ distribution in both ice-covered lakes and other types of lake systems. The difference with the MCM lakes is that they do not turn over, mix or exchange $\mathrm{CO}_{2}$ with the atmosphere to any great extent. Therefore, DIC that accumulates in the hypolimnia of the MCM lakes is maintained there. As the hypolimnetic waters age, more old carbon accumulates. So although present-day biological processes affect the $\delta^{13} \mathrm{C}$, they probably exert less influence on the deep waters of the MCM lakes than in lacustrine environments that mix on a seasonal, annual or even longer basis. The isolation of carbon into shallow and deep pools in the MCM lakes makes them unusual lakes in a global sense. However, this occurrence of carbon stratification also occurs in other polar lakes where fresh water has flowed into a depression where sea water had been trapped (Jeffries and others, 1984; Pagé and others, 1984).

The other major difference with the MCM lakes is that, in contrast to temperate systems, there is little DIC introduced to the lakes produced by organic-matter decomposition in the terrestrial realm. The $\delta^{13} \mathrm{C}$ values of $\sim 0 \%$ for the DIC entering the MCM lakes contrasts dramatically with values of $-4 \%$ to $-10 \%$ for Meech Lake and $-10 \%$ to $-14 \%$ for Lake Washington, for example (Quay and others, 1986; Wang and Veizer, 2000). This lack of input of biologically derived light $\delta^{13} \mathrm{C}$ into the surface waters of the MCM lakes helps maintain their surface waters in a state of heavier $\delta^{13} \mathrm{C}$ DIC. As mentioned above, biological fractionation via photosynthesis causes the surface water to become even more enriched in ${ }^{13} \mathrm{C}$. The importance of the ice covers, the stratification and the lack of abundant biologically derived DIC helps to make these systems different from more temperate lakes.

\section{Implications for subglacial lakes}

Our work on the perennially ice-covered lakes of the MCM clearly indicates that a 'biological signal' or an imprinting of lake biological processes occurs in the $\delta^{13} \mathrm{C}$ profiles of DIC. In this way, MCM lakes are similar to more temperate systems. What might we expect to observe in subglacial lakes such as Vostok lake? Noteworthy here is the obvious: the lack of photoautotrophic organisms in these subglacial lakes would clearly negate the DIC decrease, with subsequent enriched $\delta^{13} \mathrm{C}$ values as seen in the MCM lakes (assuming that chemoautotrophy is negligible). However, if organic-matter decomposition is occurring in specific loci (e.g. aggregates) within the subglacial lake system, increases in DIC with depleted $\delta^{13} \mathrm{C}$ values might be expected. If chemosynthesis, methanogenesis, etc., were occurring, $\delta^{13} \mathrm{C}$ analysis would aid in sorting out the location and the extent of these processes as well. The use of $\delta^{13} \mathrm{C}$ will clearly aid in our overall understanding of the nature and the impact of metabolic activity on the subglacial lake waters. Importantly, $\delta^{13} \mathrm{C}$ analysis will also aid in discerning a possible/potential lack of biological activity in these systems.

\section{CONCLUSIONS}

The $\delta{ }^{13} \mathrm{C}$ values of the DIC in the MCM lakes demonstrate the usefulness of carbon isotope analysis in describing biological activity within these systems by showing that the variation of $\delta^{13} \mathrm{C}$ in the lakes is primarily controlled by photosynthesis and decomposition activities. Landscape position (i.e. proglacial, closed-basin), legacy effects and carbonate mineral dynamics also play a role in the overall $\delta^{13} \mathrm{C}$ balance and depth profiles of the lakes. The analysis of $\delta^{13} \mathrm{C}$ in lake waters remains a powerful tool in the study of biogeochemical dynamics of aquatic systems.

\section{ACKNOWLEDGEMENTS}

We thank our MCM-LTER colleagues, especially R. Edwards and C. Takacs, for help with the collection of these samples. Discussions through the years with P.T. Doran regarding carbon isotope dynamics are also gratefully acknowledged. This work was supported by funds to K.N. from the University of Alabama and by US National Science Foundation grants OPP 9211773 and OPP 9810219. We gratefully acknowledge two anonymous reviewers of the original manuscript and the thoughtful editorial help of R. Mulvaney.

\section{REFERENCES}

Clow, G. D., C. P. McKay, G. M. Simmons, Jr and R. A. Wharton, Jr. 1988. Climatological observations and predicted sublimation rates at Lake Hoare, Antarctica. J. Climate, 1(7), 715-728.

Doran, P. T., R. A. Wharton, Jr, D.J. DesMarais and C. P. McKay. 1998. Antarctic paleolake sediments and the search for extinct life on Mars. J. Geophys. Res., 103(E12), 28,481-28,493.

Fairchild, I. J. 1993. Balmy shores and ice wastes: the paradox of carbonates associated with glacial deposits in Neoproterozoic times. In Wright, V.P., ed. Sedimentology Review 1. Oxford, Blackwell Scientific Publishers, 1-6. 
Hoffman, P. F. and D. P. Schrag. 2002. The snowball Earth hypothesis: testing the limits of global change. Terra Nova, 14, 129-155.

House, H. R., D. M. McKnight and P. von Guerard. 1995. McMurdo LTER: the influence of stream channel characteristics on streamflow and annual water budgets for lakes in Taylor Valley. Antarct. J. US, 30(5), Review 1995, 284-287.

Jeffries, M. O., H. R. Krouse, M. A. Shakur and S. A. Harris. 1984. Isotope geochemistry of stratified Lake ' $A$ ', Ellesmere Island, N.W.T., Canada. Can. J. Earth Sci., 21(4), 1008-1017.

Laybourn-Parry, J. 1997. The microbial loop in Antarctic lakes. In Lyons, E. B., C. Howard-Williams and I. Hawes, eds. Ecosystem processes in Antarctic ice-free landscapes. Rotterdam, A. A. Balkema, 231-240.

Lyons, W. B. and 7 others. 1998a. Geochemical linkages among glaciers, streams, and lakes within the Taylor Valley, Antarctica. In Priscu, J.C., ed. Ecosystem dynamics in a polar desert: the McMurdo Dry Valleys, Antarctica. Washington, DC, American Geophysical Union, 77-92. (Antarctic Research Series 72.)

Lyons, W. B., S.W. Tyler, R.A. Wharton, D. M. McKnight and B. H. Vaughn. 1998b. A Late Holocene desiccation of Lake Hoare and Lake Fryxell, McMurdo Dry Valleys, Antarctica. Antarct. Sci., 10(3), 247-256.

Lyons, W. B., A. Fountain, P. Doran, J. C. Priscu, K. Neumann and K.A. Welch. 2000. Importance of landscape position and legacy: the evolution of the lakes in Taylor Valley, Antarctica. Freshwater Biol., 43(3), 355-376.

Matsubaya, O., H. Sakai, T. Torii, H. Burton and K. Kerry. 1979. Antarctic saline lakes - stable isotopic ratios, chemical compositions and evolution. Geochim. Cosmochim. Acta, 43(1), 7-25.

McKenzie, J. 1985. Carbon isotopes and productivity in the lacustrine and marine environment. In Stumm, W., ed. Chemical processes in lakes. New York, Wiley Interscience, 99-118.

McKnight, D.M., D.K. Niyogi, A.S. Alger, A. Bomblies, P. A. Conovitz and C.M. Tate. 1999. Dry valley streams in Antarctica: ecosystems waiting for water. BioScience, 49(12), 985-995.

Neumann, K. 1999. Carbon dynamics in lakes and streams of Taylor Valley, Antarctica. (Ph.D. thesis, University of Alabama.)

Neumann, K., W.B. Lyons and D.J.D. Marais. 1998. Inorganic carbon-isotope distribution and budget in the Lake Hoare and Lake Fryxell basins, Taylor Valley, Antarctica. Ann. Glaciol., 27, 685-690.

Neumann, K., W. B. Lyons, J. C. Priscu and R. Donahoe. 2001. $\mathrm{CO}_{2}$ concentrations in perennially ice-covered lakes of Taylor Valley, Antarctica. Biogeochemistry, 56(1), 27-50.

Nezat, C.A., W. B. Lyons and K.A. Welch. 2001. Chemical weathering in streams of a polar desert (Taylor Valley, Antarctica). Geol. Soc. Am. Bull., 113(11), 1401-1407.

Pagé, P., M. Ouellet, C. Hillaire-Marcel and M. Dickman. 1984. Isotopic analyses $\left({ }^{18} \mathrm{O},{ }^{13} \mathrm{C},{ }^{14} \mathrm{C}\right)$ of two meromictic lakes in the Canadian Arctic Archipelago. Limnol. Oceanogr., 29(3), 564-573.

Priscu, J.C. and 7 others. 1999a. Carbon transformations in a perennially ice-covered Antarctic lake. BioScience, 49(12), 997-1008.

Priscu, J. C. and 11 others. 1999b. Geomicrobiology of subglacial ice above Lake Vostok, Antarctica. Science, 286(5447), 2141-2144.

Quay, P. D., S. R. Emerson, B. M. Quay and A. H. Devol. 1986. The carbon cycle for Lake Washington - a stable isotope study. Limnol. Oceanogr., 31(3), 596-611.

Rau, G.H., U. Riebesell and D. Wolf-Gladrow. 1997. $\mathrm{CO}_{2}-$ dependent photosynthetic ${ }^{13} \mathrm{C}$ fractionation in the ocean: a model versus measurements. Global Biogeochem. Cycles, 11(2), 267-278.

Siegert, M. J., M. Tranter, J.C. Ellis-Evans, J.C. Priscu and W. B. Lyons. 2003. The hydrochemistry of Lake Vostok and the potential for life in Antarctic subglacial lakes. Hydrol. Processes, 17, 795-814.

Smith, R. L., L. G. Miller and B. L. Howes. 1993. The geochemistry of methane in Lake Fryxell, an amictic, permanently ice-covered Antarctic lake. Biogeochemistry, 21(2), 95-115.

Spigel, R.H. and J.C. Priscu. 1998. Physical limnology of the McMurdo Dry Valley lakes. In Priscu, J.C., ed. Ecosystem dynamics in a polar desert: the McMurdo Dry Valleys, Antarctica. Washington, DC, American Geophysical Union, 153-187. (Antarctic Research Series 72.)

Wang, X. and J. Veizer. 2000. Respiration-photosynthesis balance of terrestrial aquatic ecosystems, Ottawa area, Canada. Geochim. Cosmochim. Acta, 64(22), 3775-3786.

Welch, K. A., W. B. Lyons, E. Graham, K. Neumann, J. M. Thomas and D. Mikesell. 1996. The determination of major element chemistry in terrestrial waters from Antarctica using ion chromatography. J. Chromatogr., Ser. A, 739, 257-263.

Wharton, R. A., Jr, C.P. McKay, G. D. Clow and D. T. Andersen. 1993. Perennial ice covers and their influence on Antarctic lake ecosystems. In Green, W. J. and E. I. Friedmann, eds. Physical and biogeochemical processes in Antarctic lakes. Washington, DC, American Geophysical Union, 53-70. (Antarctic Research Series 59.)

Wilson, A. T. 1964. Evidence from chemical diffusion of a climatic change in the McMurdo dry valleys 1,200 years ago. Nature, 201(4195), 176-177. 